ISSN : $2302-1590$

E-ISSN: $2460-190 \mathrm{X}$

ECONOMICA

Journal of Economic and Economic Education Vol.4 No.2 (288-295)

\title{
PENGARUH PENGAWASAN KEPALA SEKOLAH TERHADAP KINERJA GURU PADA SD NEGERI BINAAN TANJUNGPINANG
}

\author{
Satriadi \\ Jurusan Manajemen Sekolah Tinggi Ilmu Ekonomi Pembangunan Tanjung Pinang \\ E-mail: satriadid@ymail.com
}

Submitted:2016.04.06 Reviewed: 2016.07.01 Accepted: 2016.07.01

http://dx.doi.org/10.22202/economica.2016.v4.i2.583

\begin{abstract}
Supervision meant that assistance in the development of the teaching-learning situation in order to obtain better conditions. By there were oversight was expect to determine the success of an organization in setting goals. But in fact, this controls was often a problem for the leadership.The purpose of this research was determined the influence of supervision by heddmaster to teacher's performance in the elementary school development at Tanjung Pinang city. The research of population was the headmaster and teachers at the elementary school Tanjungpinang city that were 144 people. They were have 100 teachers with headmaster key informants by 4 people, with kinds of sampling technique and then measured quantitatively by using Likert scale. The data had been collected through quesioners, interviews and observations were analyze with statistical analysis. The result of influence the level of supervision by the headmaster on the performance of elementary school teachers in Tanjungpinang city was moderate and indicated that therewere significant effects between supervision by the headmaster in performance of elementary school teachers at Tanjungpinang city.
\end{abstract}

\begin{abstract}
Abstrak
Supervisienberarti bantuan dalam pengembangan situasi belajar-mengajar untuk mendapatkan kondisi yang lebih baik. Dengan ada pengawasan itu berharap untuk menentukan keberhasilan suatu organisasi dalam menetapkan tujuan. Namun pada kenyataannya, kontrol ini sering menjadi masalah bagi leadership.Tujuan penelitian ini ditentukan pengaruh pengawasan heddmaster untuk kinerja guru dalam pengembangan sekolah dasar di kota Tanjung Pinang. Penelitian dari populasi adalah kepala sekolah dan guru di sekolah dasar Tanjungpinang kota yang 144 orang. Mereka memiliki 100 guru dengan informan kunci kepala sekolah oleh 4 orang, dengan jenis teknik sampling dan kemudian diukur secara kuantitatif dengan menggunakan skala Likert. Data telah dikumpulkan melalui kuisioner, wawancara dan pengamatan dianalisis dengan analisis statistik. Hasil pengaruh tingkat pengawasan oleh kepala sekolah terhadap kinerja guru SD di kota Tanjungpinang adalah moderat dan menunjukkan bahwa efek signifikan Therewere antara supervisi oleh kepala sekolah dalam kinerja guru SD di kota Tanjungpinang.
\end{abstract}

Keywords: Supervision, Performance 


\section{PENDAHULUAN}

Pengawasan merupakan unsur di dalam manajemen. Kegiatan pengawasan secara berkelanjutan sangat diperlukan untuk membantu kelancaran tugas sehingga kinerja guru meningkat dan mampu berprestasi serta mampu mengejar ketinggalan, bersaing dengan sekolah lain.

Menurut Depdikbud, Biri perencanaan (Atmodiwiryo; 2011:56) "Pengawasan adalah upaya melihat apakah pelaksanaan kegiatan sesuai dengan rencana, peraturan perundangundangan yang berlaku serta kebijaksanaan pimpinan dalam rangka mencapai tujuan secara efektif dan efisien.

Sedangkan menurut Moekijat (1994:185) "Pengawasan mempunyai peranan penting bagi manajemen kepegawaian karena ia mempunyai hubungan yang terdekat dengan pegawai-pegawai perorangan secara langsung dan baik buruknya pegawai bekerja tergantung dari bagaimana ia mengawasi cara kerja pegawainya dan mendekati para pegawainya agar mereka melaksanakan pekerjaannya dengan baik dan tidak ada unsur paksaan hanya karena mereka diawasi."

Kegiatan pengawasan oleh kepala sekolah akan berpengaruh secara psikologis terhadap kinerja guru. Guru yang puas dengan pengawasan oleh kepala sekolah maka ia akan bekerja dengan sukarela yang akhirnya dapat membuat produktivitas kerja guru meningkat. Tetapi jika guru kurang puas terhadap pelaksanaan pengawasan oleh kepala sekolah maka guru dalam bekerja kurang bergairah, hal ini mengakibatkan produktivitas guru menurun.

Pengawasan yang dilakukan kepala sekolah sebelumnya banyak mengalami kendala teknis seperti rapat dan sebagainya. Kemudian kinerja guru yang semakin menurun akibat banyaknya beban kerja yang diterima oleh para guru, dan pengawasan yang kurang dari kepala sekolah untuk mengantisipasi masalah kinerja guru tersebut. Kemudian jika dilihat dari segi dokumen evaluasi diri sekolah tahun 2011 serta laporan bulanan, masih terdapat kualifikasi guru yang masih belum sesuai kriteria yang ditentukan yakni dari segi ijazah guru yang masih banyak yang belum setara Strata-1 (S-1) yakni \pm $50 \%$.

Hal ini dikarenakan masih banyak sekolah yang kekurangan guru yang berkompeten terutama yang sudah Pegawai Negeri Sipil. Sebenarnya hal tersebut sudah menyalahi aturan dalam UU Guru dan Dosen No.14 Tahun 2005 dan PP No. 19 Tahun 2005 yakni pendidikan guru seharusnya S-1 berasal dari FKIP/IKIP. Sehingga akibat dari hal tersebut bisa mempengaruhi kinerja guru itu sendiri. Untuk itulah diperlukan sebuah pengawasan yang dilakukan oleh kepala sekolah yang tujuannya adalah untuk membantu guru-guru melihat dengan jelas tujuan pendidikan dan berusaha mencapai tujuan pendidikan itu dengan membina dan mengembangkan metode-metode dan prosedur pengajaran yang lebih baik.

\section{Rumusan Masalah}

Berdasarkan latar belakang dan batasan masalah yang telah diuraikan diatas, maka penulis merumuskan permasalahan sebagai berikut :

1. Bagaimana pengaruh pengawasan oleh kepala sekolah terhadap kinerja guru SD Negeri Binaan se-Kota Tanjungpinang?"

\section{Tujuan Penelitian}

Adapun tujuan dalam penelitian ini adalah:

1. Untuk mengetahui pengaruh pengawasan oleh Kepala Sekolah terhadap kinerja Guru SD Negeri Binaan se-Kota Tanjungpinang.

\section{Pengawasan}

Menurut Moekijat (1990:80) : Pengawasan adalah hal yang dilakukan, artinya hasil pekerjaan, menilai hasil pekerjaan tersebut, dan apabila perlu mengadakan tindakan-tindakan perbaikan sehingga hasil pekerjaan sesuai dengan rencana. Sedangkan menurut LAN (Atmodiwiryo; 2011:56) : Pengawasan adalah suatu proses kegiatan seorang pimpinan untuk menjamin agar pelaksanaan kegiatan organisasi sesuai dengan rencana, kebijaksanaan, dan ketentuan-ketentuan yang telah ditetapkan. 
Menurut Sondang Siagian (Atmodiwiryo; 2011:56) : Pengawasan adalah proses pengamatan dari pelaksanaan seluruh kegiatan organisasi untuk menjamin agar semua pekerjaan yang sedang dilaksanakan berjalan sesuai dengan rencana yang ditetapkan.

Menurut The Liang Gie (Atmodiwiryo; 2011:56) : Pengawasan adalah pemeriksaan, mencocokkan dan mengusahakan agar pekerjaan-pekerjaan terlaksana sesuai dengan rencana yang telah ditetapkan serta hasil yang dikehendaki.

Dari beberapa pendapat yang memberikan pengertian tentang pengawasan maka dapat disimpulkan bahwa pengawasan merupakan salah satu pekerjaan yang dilaksanakan dalam kegiatan manajerial untuk menjamin terealisasinya semua rencana yang telah ditetapkan sebelumnya serta pengambilan tindakan perbaikan bila diperlukan. Tindakan perbaikan diartikan tindakan yang diambil untuk menyesuaikan hasil pekerjaan dengan standar. Tindakan perbaikan ini membutuhkan waktu dan proses agar terwujud untuk mencapai hasil yang diinginkan. Karena laporan-laporan berkala sangat penting sebab dalam laporan itu dapat diketahui situasi yang nyata. Apabila terjadi penyimpangan, tindakan perbaikan segera dapat diambil, sehingga kemungkinan resiko dan kerugian perusahaan dapat diminimalkan.

Agar pengawasan dapat berjalan dengan baik ada beberapa dimensi-dimensi pengawasan yang perlu dipahami oleh pengawas. Handoko (1998: 363) mengatakan terdapat 5 (lima) dimensi pengawasan yaitu :

1) Penetapan standar hasil yang diinginkan;

2) Penentuan pengukuran pelaksanaan kegiatan;

3) Pengukuran pelaksanaan kegiatan;

4) Pembandingan pelaksanaan dengan standar dan analisa penyimpangan;

5) Pengambilan tindakan korektif bila diperlukan.

Sedangkan, Robbins and Coulter (Monang; 2008:64) terdiri dari empat dimensi yaitu:

1) Menetapkan standar (Standards) yakni penetapan patokan (target) atau hasil yang diinginkan, untuk dapat dilakukan sebagai perbandingan hasil ketika berlangsungnya kegiatan organisasi. Standar juga merupakan batasan tentang apa yang harus dilakukan dalam melaksanakan suatu kegiatan untuk mencapai tujuan dan target organisasi.

2) Pengukuran (Measurement) yakni proses yang berulang-ulang dilakukan dan terus menerus dan benar, baik intensitasnya dalam bentuk pengukuran harian, mingguan, atau bulanan sehingga tampak yang diukur antara mutu dan jumlah hasil.

3) Membandingkan (Compare) adalah membandingkan hasil yang dicapai dengan target atau standar yang telah ditetapkan, mungkin kinerja lebih tinggi atau lebih rendah atau sama dengan standar.

4) Melakukan tindakan (Action) adalah keputusan mengambil tindakan koreksikoreksi atau perbaikan. Bilamana telah terjadi penyimpangan (deviasi) antara standar dengan realisasi perlu melakukan tindakan follow-up berupa mengoreksi penyimpangan yang terjadi.

\section{Kinerja Guru}

Menurut Armstrong dan Baron (Wibowo, 2012) Kinerja merupakan hasil pekerjaan yang mempunyai hubungan kuat dengan tujuan strategis organisasi, kepuasan konsumen dan memberikan kontribusi ekonomi. Menurut Suprihanto (Supardi, 2014) Kinerja adalah hasil kerja seseorang dalam suatu periode tertentu yang dibandingkan dengan beberapa kemungkinan, misalnya standar target, sasaran, atau kriteria yang telah ditentukan terlebih dahulu.

Menurut Supardi (2014) yang dimaksud dengan kinerja guru adalah kemampuan dan keberhasilan guru dalam melaksanakan tugas-tugas pembelajaran yang ditunjukkan oleh indikator-indikator : kemampuan menyusun rencana pembelajaran, kemampuan melaksanakan pembelajaran, kemampuan mengadakan hubungan amtar pribadi, kemampuan melaksanakan pengayaan, dan kemampuan melaksanakan remedial. 
Berdasarkan pendapat-pendapat di atas maka dapat disimpulkan bahwa kinerja guru adalah hasil kerja yang telah dicapai oleh seseorang dalam suatu organisasi untuk mencapai tujuan berdasarkan standarisasi atau ukuran dan waktu yang disesuaikan dengan jenis pekerjaannya dan sesuai dengan norma dan etika yang telah ditetapkan.

Tugas Kepala Sekolah terhadap guru salah satunya adalah melakukan penilaian atas kinerjanya. Penilaian ini mutlak dilaksanakan untuk mengetahui kinerja yang telah dicapai oleh guru. Apakah kinerja yang dicapai setiap guru baik, sedang, atau kurang. Penilaian ini penting bagi setiap guru dan berguna bagi sekolah dalam menetapkan kegiatannya.

Penilaian kinerja menurut Simamora (2004 : 415) adalah alat yang berfaedah tidak hanya untuk mengevaluasi kerja dari para karyawan, tetapi juga untuk mengembangkan dan memotivasi kalangan karyawan.Sejalan dengan pendapat Hasibuan (2000: 87) penilaian prestasi adalah kegiatan manajer untuk mengevaluasi prestasi kerja karyawan serta menetapkan kebijaksanaan selanjutnya. Sehubungan dengan hal tersebut maka penilaian kinerja guru berdasarkan Standar Kompetensi Guru

Menurut Mitchel (Soedarmayanti ; 2001:51), menyebutkan aspek-aspek yang meliputi kinerja yang dapat dijadikan ukuran kinerja seseorang, yaitu:

1. Kualitas Kerja (quality of work) adalah suatu hasil yang dapat diukur dengan efektifitas dan efisiensi suatu pekerjaan yang dilakukan oleh sumber daya manusia atau sumber daya lainnya dalam pencapaian tujuan atau sasaran perusahaan dengan baik dan berdaya guna

2. Ketepatan waktu (promptness) adalah sesuai tidaknya dengan waktu yang direncanakan. Pengukuran ketepatan waktu merupakan jenis khusus dari pengukuran kuantitatif yang menentukan ketepatan waktu penyelesaian suatu kegiatan.

3. Inisiatif (inisiative) adalah kemampuan seseorang dalam melakukan sesuatu tanpa menunggu perintah lebih dahulu dengan tujuan untuk memperbaiki atau meningkatkan hasil pekerjaan, menciptakan peluang baru atau untuk menghindari timbulnya masalah.

4. Kemampuan (capability) adalah kesanggupan untuk mengerjakan tugas atau pekerjaan.

5. Komunikasi (communication) adalah proses penyampaian suatu pernyataan oleh seseorang kepada orang lain.

\section{Model Penelitian}

Model penelitian yang akan dibahas adalah pengawasan oleh kepala sekolah dan kinerja guru.

\begin{tabular}{c}
$\begin{array}{c}\text { PENGAWASAN KEPALA } \\
\text { SEKOLAH }(\mathrm{X})\end{array} \longrightarrow$ \\
KINERJA GURU \\
$\ldots$. \\
\hline
\end{tabular}

\section{Penelitian Terdahulu}

Penelitian terlebih dahulu Muhidin (2006 : 16) dengan judul "Pengaruh Pengawasan Kepala Bagian Terhadap Kinerja Pegawai Pada Bagian Distribusi Perusahaan Daerah Air Minum (PDAM) Kota Bandung" yakni besarnya pengaruh pengawasan langsung terhadap kinerja pegawai adalah $30,06 \%$, dan besarnya pengaruh pengawasan tidak langsung terhadap kinerja pegawai adalah sebesar $19,92 \%$, serta pengaruh pengawasan langsung dan tidak langsung secara simultan terhadap kinerja pegawai adalah sebesar 49,98\%).
Kemudian berdasarkan penelitian Kurniawati (2007 : 99) dengan Judul "Pengaruh Supervisi Kepala Sekolah dan Motivasi Kerja terhadap Kinerja Guru SMK Negeri 1 Purbalingga" yakni berdasarkan hasil analisis regresi terutama dari hasil uji parsial diperoleh nilai $\mathrm{p}$ value $=0,001$. Nilai $\mathrm{p}$ value tersebut kurang dari taraf signifikansi 0,05 yang berarti bahwa hipotesis yang menyatakan ada pengaruh supervisi terhadap kinerja guru di SMK Negeri 1 Purbalingga diterima karena signifikan. Berdasarkan data yang diperoleh ternyata kinerja guru tergolong baik. Kinerja guru tersebut tidak 
lepas dari suatu evaluasi, kritikan maupun saran dari berbagai pihak. Salah satunya adalah karena pengaruh supervisi. Disini terlihat bahwa supervisi memang berpengaruh terhadap kinerja guru khususnya di SMK Negeri 1 Purbalingga.

Jadi dapat disimpulkan bahwa proses pengawasan yang dilakukan oleh kepala sekolah kepada guru sangat berpengaruh terhadap kinerja guru tersebut, karena banyak sekali orang yang akan bekerja secara baik apabila mereka diawasi. Akan tetapi tidak semua gur seperti itu, semua kembali pada pribadi masing-masing.

\section{Hipotesis}

Berdasarkan uraian dalam kerangka pemikiran tersebut diatas, maka dapat disimpulkan hipotesis adalah Pengawasan Kepala Sekolah berpengaruh signifikan terhadap kinerja guru.

\section{METODE PENELITIAN}

Pendekatan penelitian yang digunakan dalam penelitian ini adalah pendekatan kuantitatif, sementara jenis penelitiannya adalah asosiatif sedangkan metodenya yakni deskriptif analitis dengan alat analisa data menggunakan regresi liner berganda. Data dikumpulkan melalui pengisian angket atau kuesioner. Melalui penelitian ini diharapkan dapat diketahui pengaruh pengawasan Kepala Sekolah terhadap kinerja guru pada SD Negeri Binaan Sekota Tanjungpinang.

Pada penelitian ini populasinya adalah seluruh guruSD Negeri Binaan Sekota Tanjungpinang, dengan jumlah 140orang. Sedangkan sampelnya berjumlah 100 orang yang didapat dari tabel penentuan populasi tertentu yang dikembangkan dari Isaac dan Michael. Penelitian ini menggunakan data primer yang dikumpulkan dengan menggunakan kuesioner mengenai pengawasan dan kinerja guru.

Variabel penelitian ini terdiri dari variabel bebas $(\mathrm{X})$ yaitu pengawasan kepala sekolah serta variabel terikat (Y) yaitu kinerja guru. Pengukuran variabel pengawasan kepala sekolah dan kinerja guru dilakukan dengan menggunakan skala Likert yaitu: Kategori
Sering/Baik $=3$; Kategori Kadang/Cukup Baik $=2$; dan Kategori Tidak Pernah/Tidak Baik $=1$.

Dalam rangka memperjelas pengukuran variabel, ada beberapa definisi operasional yang digunakan dalam penelitian ini. Pengawasan adalah upaya kepala sekolah dalam membina guru SD Negeri Binaan SeKota Tanjungpinang agar para guru dapat meningkatkan kualitas mengajarnya serta mengadakan perubahan dengan cara meningkatkan hasil belajar siswa SD Negeri Binaan Se-Kota Tanjungpinang. Indikator variabel pengawasan adalah: a. Menetapkan standar; b. pengukuran; c. membandingkan; d. melakukan tindakan. Kinerja merupakan kemampuan yang ditunjukkan oleh guru SD Negeri Binaan se-kota Tanjungpinang dalam melaksanakan tugas dan pekerjaannya sesuai dengan Rencana Kerja Sekolah. Indikatornya adalah: a. kualitas kerja; b. ketepatan waktu; c. inisiatif; d. kemampuan; e. kerjasama.

Program yang digunakan untuk menguji validitas dan reliabilitas instrumen adalah program komputer Statistical Program For Social Science (SPSS) versi 20 yang terdiri dari uji validitas dan reliabilitas. Dari 42 daftar pertanyaan (Questioner) yang dijawab dan dikembalikan responden, penulis menginput nilai-nilainya untuk bahan pengujian. Uji validitas digunakan untuk mengukur valid atau tidaknya suatu kuesioner. Sedangkan uji reliabilitas digunakan untuk menguji sejauh mana keandalan suatu alat pengukur untuk dapat digunakan lagi untuk penelitian yang sama. Pengujian reliabilitas dilakukan dengan menggunakan teknik analisis Cronbach Alpha.

Uji validitas yang digunakan dalam penelitian ini adalah uji validitas butir. Ketentuan apakah suatu butir instrumen valid atau tidak adalah melihat nilai probabilitas koefisien korelasinya. Menurut Ghozali dalam Rumengan (2013, 204), uji signifikansi dilakukan dengan membandingkan nilai $r_{\text {hitung }}$ dengan $r_{\text {tabel. }}$. Jika $r_{\text {hitung }}$ lebih besar dari $r_{\text {tabel }}$ dan nilai positif, maka butir pertanyaan dan indikator tersebut dinyatakan valid. 
Hasil uji validitas menunjukkan bahwa masing-masing butir yang terdapat dalam semua pertanyaan pada kedua variabel dalam penelitian ini yaitu pengawasan kepala sekolah dan kinerja guru dapat dinyatakan valid dan layak digunakan dalam analisis data.

$\begin{array}{ccc}\text { Pengujian } & \text { reliabilitas berkaitan } \\ \text { dengan adanya } & \text { kepercayaan } & \text { terhadap }\end{array}$ instrumen. Suatu instrumen dapat memiliki tingkat kepercayaan yang tinggi (konsisten) jika hasil dari pengujian menunjukkan hasil yang tetap. Dengan demikian, masalah reliabilitas instrumen berhubungan dengan masalah ketepatan hasil. Uji reliabilitas dilakukan untuk mengetahui tingkat kestabilan suatu alat ukur. Pada penelitian ini, butir instrumen yang valid diuji reliabilitasnya dengan pengujian reliabilitas dilakukan dengan menggunakan Cronbach Alpha. Menurut Nunanly dalam Rumengan (2010), dikatakan reliabel bila hasil Alpha > 0,60 . Hasil uji reliabilitas dapat dilihat pada Tabel 1 berikut ini:

Tabel 1. Hasil Uji Reliabilitas Variabel Xdan Y

\begin{tabular}{ccc}
\hline Variabel & Nilai Reliabilitas & Kesimpulan \\
\hline Pengawasan $(\mathrm{X})$ & 0.620 & Reliabel \\
Kinerja ( Y ) & 0.832 & Reliabel
\end{tabular}

Sumber: Data diolah, 2013

Metode analisis data yang digunakan dalam penelitian ini adalah analisis Regresi Linier Berganda. Untuk menguji hipotesis yang diajukan, yaitu bahwa pengawasan kepala sekolah berpengaruh signifikan baik secara parsial maupun simultan terhadap kinerja guru yang dilakukan dengan uji-t dan uji F. Dengan analisis regresi akan dapat dilihat variabel manakah yang paling dominan dalam mempengaruhi kinerja karyawan yaitu dengan melihat nilai koefisien beta-nya dan persamaannya adalah sebagai berikut: $\mathbf{Y}=\mathbf{a}+$ $\mathbf{b}_{1} \mathbf{X}_{1}+\mathbf{e}$

Keterangan: $\mathrm{Y}=$ Kinerja; $\mathrm{X}=$ Pengawasan Kepala Sekolah

\section{PEMBAHASAN}

Hasil perhitungan analisis regresi linier berganda secara lengkap dapat dilihat pada tabel 2. berikut ini:

Tabel 2. Ringkasan Hasil Uji Regresi Linier Berganda

\begin{tabular}{lcccc}
\hline \multicolumn{1}{c}{ Variabel } & Beta & Deviasi Standar & Nilai-t & Sig. \\
\hline Konstanta & 14.085 & 3.987 & 3.533 & .001 \\
Pengawasan & .394 & .114 & 3.444 & .001 \\
\hline $\mathrm{R}=0,577 \quad ; \mathrm{R}^{2}=0,332$ & $; \mathrm{F}=17,818$ & $;$ Sig.F $=0,000$ &
\end{tabular}

Berdasarkan tabel 2. diatas, dihasilkan persamaan regresi berganda yaitu: $\mathrm{Y}=14,085+0,394 \mathrm{X}$. Dalam persamaan regresi tersebut, dapat diketahui bahwa variabel motivasi memiliki koefisien sebesar 0,394. Hasil koefisien korelasi berganda adalah 0,577 , sedangkan nilai $\mathrm{R}$-squareadalah
0,332 atau 33,2\%. Hasil ini mengindikasikan bahwa 33,2\% variabel kinerja guru (Y) dapat dijelaskan oleh variabel pengawasan kepala sekolah (X), sisanya dipengaruhi oleh variabel lain yang tidak diteliti.

$$
\text { Untuk menguji pengaruh }
$$

pengawasan kepala sekolah secara parsial 
terhadap kinerja guru pada SD Negeri Binaan Tanjungpinang digunakan uji-t.

Dengan menggunakan uji-t tersebut, hasil pengujian dengan SPSS untuk variabel $X$ (pengawasan) diperoleh nilai $t_{\text {hitung }}=3,444$ dengan nilai probabilitas $t$ (Sig.) adalah sebesar 0,001 (Sig.0,001 $\left.<\alpha_{0,05}\right)$. Dengan demikian Ho ditolak dan Ha diterima, maka hipotesisnya diterima. Dapat disimpulkan bahwa pengawasan kepala skeolah (X) secara parsial mempunyai pengaruh yang signifikan terhadap kinerja guru (Y) pada SD Negeri Binaan Tanjungpinang.

$$
\text { Untuk menguji pengaruh }
$$

pengawasan kepala sekolah secara simultan terhadap kinerja guru pada SD Negeri Binaan Tanjungpinang. digunakan uji F. Dengan menggunakan uji $\mathrm{F}$ tersebut, Hasil pengujian dengan SPSS variabel independen secara bersama-sama diperoleh nilai $F_{\text {hitung }}=17,818$ dengan nilai probabilitas $\mathrm{F}$ (Sig.) adalah sebesar $\quad 0,000 \quad\left(\mathrm{Sig}_{\cdot 0,000}<\alpha_{0,05}\right)$. Dengan demikian Ho ditolak dan Ha diterima, maka hipotesisnya juga diterima. Dapat disimpulkan bahwa pengawasan kepala sekolah (X) secara simultan mempunyai pengaruh yang signifikan terhadap kinerja guru (Y) pada SD Negeri Binaan Tanjungpinang.

Normal atau tidaknya suatu data yang akan diolah dalam penelitian dapat diketahui dengan menggunakan uji normalitas. Uji normalitas bertujuan untuk menguji apakah dalam model regresi, variabel pengganggu atau residual memiliki distribusi normal. Jika data menyebar di sekitar garis diagonal dan mengikuti arah garis diagonal maka model regresi memenuhi asumsi normalitas (Rumengan, 2010). Dalam penelitian ini, data yang akan diolah berdistribusi normal, dimana data menyebar di sekitar garis diagonal dan mengikuti arah garis diagonal.

\section{PENUTUP}

Dari hasil analisis yang telah dibahas sebelumya, maka ditarik kesimpulan sebagai berikut:

1. Pengawasan Kepala Sekolah (X) secara parsial mempunyai pengaruh yang signifikan terhadap kinerja guru (Y) pada
SD Negeri Binaan Tanjungpinang dengan perolehan nilai $\mathrm{t}$ hitung $=3,444$ dengan nilai probabilitas $\mathrm{t}$ (Sig) adalah sebesar 0,001 (Sig.0,001< <0,05).

2. Dari uji F ( Simultan ) diperoleh nilai F hitung sebesar 17,818 dengan Sig.0,000 < a 0,05, menunjukkkan bahwa Ho ditolak dan Ha diterima, berarti pengawasan kepala sekolah $(\mathrm{X})$ berpengaruh secara signifikan terhadap kinerja guru $(\mathrm{Y})$ pada taraf $\alpha=0,05$ pada SD Negeri Binaan Tanjungpinang.

Dengan demikian dapat dikatakan bahwa pengawasan kepala sekolah berpengaruh secara signifikan terhadap kinerja guru SD Negeri Binaan Tanjungpinang. Hal ini berarti pengawasan yang diberikan oleh kepala sekolah kepada para guru memiliki peran penting dalam meningkatkan kinerja para gurunya yang pada akhirnya dapat meningkatkan kinerja SD Negeri Binaan Tanjungpinang. Dalam penelitian ini, disarankan agar pengawasan yang diberikan kepala sekolah terhadap guru agar dipertahankan dan ditingkatkan sehingga tidak terjadi penurunan kinerja. Dengan demikian, tujuan sekolah dapat dicapai dengan baik.

\section{DAFTAR PUSTAKA}

10.22202/economica.2016.v4.i2.583

Arikunto, Suharsimi. 1998. Prosedur Penelitian Suatu Pendekatan Praktek. Jakarta: Rineka Cipta.

Atmodiwiryo, Soebagio. 2011. Manajemen Pengawasan dan Supervisi Sekolah. Jakarta : PT.Ardadizya Jaya.

Gunawan, Muhammad Ali. 2007. Kajian Penyusunan Instrumen Non Kognitif dengan Variabel Kinerja Guru.

Handoko, T. Hani. 1990. Manajemen Sumber Daya Manusia. Jakarta: Ghalia.

. 1998. Manajemen. Edisi ke-2. Yogyakarta : BPFE.

Hasibuan, S.P Malayu. 2000. Manajemen Dasar, Pengertian dan Masalah. Jakarta: Bumi Aksara.

Kurniawati, Laeli. 2007. "Pengaruh Supervisi Kepala Sekolah dan Motivasi Kerja Terhadap Kinerja Guru SMKN 1 
Purbalingga". Skripsi; FEKONUNS, Semarang.

Mangkunegara, A.A.Anwar Prabu. 2005. Evaluasi Kinerja SDM. Bandung : Refika Aditama.

Moekijat. 1990. Pengawasan Efektif. Bandung : CV. Pionir Jaya.

Muhidin, Sambas Ali. 2006. Pengaruh Pengawasan Kepala Bagian Terhadap Kinerja Pegawai Pada Bagian Distribusi Perusahaan Daerah Air Minum (PDAM) Kota Bandung. Jurnal.

Muslim S.TR, Agus. 2009. Modul Pengantar Statistik : Korelasi Product Moment. Tanjungpinang : STISIPOL Raja Haji Tanjungpinang.

Purwanto, Drs. M. Ngalim. 2007. Cetakan XVII. Administrasi dan Supervisi Pendidikan. Bandung : PT. Remaja Rosdakarya.

Sadili, Samsudin. 2005. Manajemen Sumber Daya Manusia. Bandung: Pustaka Setia

Simamora, Henry. 2004. Manajmen Sumber Daya Manusia. Yogyakarta : YKPN.

Sitorus, Monang. 2008. Pengaruh DimensiDimensi Pengawasan Terhadap Perilaku Aparatur dalam Pelayanan Perijinan Pada Dinas Perindustrian dan Perdagangan Kota Medan. Jurnal; Universitas HKBP Nommensen, Medan.

Soedarmayanti. 2001. Sumber Daya Manusia dan Produktivitas Kerja. Bandung : CV Mandar Maju.

Sondang P Siagian. 2002. Manajemen Sumber Daya Manusia. Jakarta : Bumi

Aksara.

Sugiyono. 2009. Cetakan XVII. Metode Penelitian Administrasi. Bandung: Alfa Beta.

Umar, Husein, 2004. Metode Riset Ilmu Administrasi. Jakarta : PT. Gramedia Pustaka Utama.

Yamin, Martinis dan Maisah. 2010. Standarisasi Kinerja Guru. Jakarta : Gaung Persada. 